\title{
The Internationalization of Firms: Some Lessons from ASEAN Firms
}

\author{
Mohamad Hanapi Mohamad \\ School of International Studies \\ Universiti Utara Malaysia \\ mhm177@uum.edu.my
}

DOI: https://doi.org/10.32890/jis2016.12.3

Abstract

\begin{abstract}
In the last 50 years the debate on the development of international business remained unsettled, especially that concerning the establishment of multinational firms from developing countries. Using the Ownership Locational Internalization (OLI) Model this paper examined the formation of multinational firms from ASEAN countries. We found positive similarities in the advancement of the firm's specific ownership advantages such as skills, management know-how, $R \& D$ and technological capabilities. Unlike the firms from developed countries, the firms from developing countries adopted local elements in their products and services.
\end{abstract}

Keywords: Multinational firms, ownership locational internalization, newly industralized countries, less developed countries.

\section{Introduction}

Multinational firms once seen as the product of the advanced industrial nations are now found arising in so-called newly industrialized countries (NICs) and the less developed countries (LDCs). Evidence of this can be found in the Fortune Annual Survey of The 500 Largest Industrial Corporations (Fortune, 2015). While the geographical origins have changed, the characteristics of the international business operations have remained unchanged. Most typical is the nature and size of their sales. The sales recorded by some multinational corporations can go into billions of US dollars, often far more than the gross national products attained by some countries. Table 7 shows the list of the global biggest corporations for 2015. For example, the sales recorded by Wal-Mart Stores for the year 2015 was USD 483 billion (Fortune, 2015).

This sum does not come from a single activity or production of a single product but comes from a wide range of operations. This multi-product approach and the development of new products is a new phenomenon of multinational firms. It contrasts with the traditional single product company usually extracting raw materials to supply the parent company. A good example of this diversified multinational is Samsung whose its recorded sales were USD 308 billion in 2014 (Fortune, 2015). Samsung produces electronic and electrical equipment 
and accessories. In the case of ASEAN multinationals, Sampoerna, Sime Darby and Siam Cement are among the significant competitors in the global markets even for fairly technical non-labor intensive products and services (Nikkei, 2016).

Nevertheless, much of the analysis and debate over the impact of the multinational corporations remain mostly theoretical, as there are relatively few empirical studies on the impact of the multinational corporations on a particular regional economy. One of the reasons for this is the absence of adequate theoretical understanding of the framework of multinational corporations (Mohamad \& Mohamad Hanapi, 2012). The aim of this paper is to highlight the contribution of the multinational corporations on regional trade and the economic development of ASEAN. In particular, our main focus in this paper is to examine whether the upsurge in trade holds good in explaining the types of international market entry and the development methods currently being undertaken by firms in ASEAN. This paper also attempts to identify the pattern of international involvement of the ASEAN firms in the future given the recurring complexity and dynamism of international business. This paper is organized into five sections. Section two analyses in general some salient features and performances of the world trade and the ASEAN corporate performances. Section three highlights the internal organization and corporate entity of multinational firms. The main objective of this section is to present the current thinking concerning the theoretical explanation of the multinational firm. Section four provides a detailed description of the investigation. Finally, section five provides the conclusion of the paper.

\section{World Trade and ASEAN Economy}

Historically, international business activity initially took the form of exporting and importing. Exporting is the selling of products made in one's own country for use or resale in another country. Importing is the buying of products made in other countries for use or resale in one's own country. Table 1.0 presents a number of comparisons between international trade flows during the post-World War II period and those that have been occurring most recently. For instance, world trade flows were recorded at USD 62 billion in 1948 and maintained a fairly progressive growth in their aggregate trade flows up until the 1970s. By 1983, world trade flows were USD 594 billion and by 2014, world trade recorded USD 18494 billion. The United States in particular was as the major player in international trade but China took over as the main exporter in 2014 having a share of $12.3 \%$ of the world total export. While the US was still dominating as the world importer, China had increased her share of the world total import to $10.3 \%$ (WTO, 2015).

Another interesting feature of the global trade is the expanding volume of trade in various highly aggregated industrial sectors. The huge shift in the composition of trade in the 1980s was toward manufacturing goods and in the 1990s toward minerals and away from other industries. Trade in minerals accounted for about $17 \%$ of the total trade in the 1980s, but for about $30 \%$ of the total trade in the 1990s, after the two major OPEC price hikes. 
Manufacturing decreased from about $61 \%$ of the total exports in 1970 to about $55 \%$ of the total export in 1980. The original relationship was re-established approximately in 1985 due to the oil price decline, and it continues until present (WTO, 2015).

The second major form of international business activity is international investments. International investment is movement of capital which is supplied by the residents of one country to residents of another country. This type of investment is divided into two major categories (Mohamad \& Mohamad Hanapi, 2012). The first type is foreign direct investment (FDI). Foreign direct investment is investment made for the purpose of actively controlling property, assets, or companies located in host countries. The stock of foreign direct investment stood at USD 1.23 trillion in 2014 (UNCTAD, 2015). Traditionally, the United States accounted for about half of the total investment during the period after World War II, however, the total investment declined to less than $40 \%$ by 1983 . After rebuilding their economies from war damage, both German and Japanese firms showed the most rapid growth in FDI during the post-war period. In fact, both of the traditional powers of the early $20^{\text {th }}$ century, the United States and the United Kingdom, shown a decline in their shares of global FDI, though firms from both countries continue to invest abroad and their FDI shares still lead compared to those of other countries. FDI undertaken by less developed countries accounted for less than $10 \%$ of the total investment reported during the period. In terms of major economic areas, the industrialized countries dominate world trade, accounting for about $68 \%$ of the world trade in recent years. Details of trade on a regional basis are provided in Tables 2 and 3. These tables also show the relative importance of the European Union, the United States and Japan in terms of both imports and exports. Among the developing countries the tables show that Asia accounts for well over one-half of their imports and exports, while the Western Hemisphere and the Middle East each account for $15 \%$ or less of developing country trade.

In the case of the Association of Southeast Asian Nations (ASEAN) which has a population of about 500 million people, the transformation of global trade which had occurred in the developed countries over the decades, also had considerable impact on their economies. As ASEAN is moving towards a comprehensive single market by 2020, ASEAN countries have been restructuring their economies by adopting economic policies that have fostered exports and inward foreign investment. The fluctuation in commodity prices and the expanding markets of the United States and the European Union compelled the ASEAN countries that had been dependent on those products for export revenue, to promote more diversity in their economic structure. Structural change has transformed their economic profiles from being exporters of agricultural commodities and unprocessed goods to become exporters of light manufactured goods. Besides, Northeast Asian investment has contributed to Southeast Asia is rapid growth in order to take advantage of its large supply of cheap labour to manufacture goods. The ASEAN economies of Singapore, Malaysia, Thailand, Philippines and Indonesia have benefited most. Table 4.0 and Table 5.0 provide data on the total trade of the ASEAN countries. Total trade for ASEAN was recorded at USD 2523 billion while the flow of capital stock was $2.8 \%$ of the total foreign direct investment flow (UNCTAD, 
2015) In Malaysia, inflows of foreign direct investment have contributed around $20 \%$ of gross domestic capital formation and provided access to improved technological production and export markets.

Economic growth in Southeast Asia is projected to grow moderately at $6 \%$ throughout this decade (WTO, 2015). The Philippines has surpassed the difficult years of the 1980s and 1990s in the process of attaining modest economic recovery (WTO, 2015). The peaceful presidential election will rebuild the people's confidence in political stability and effective economic management. Foreign investment will pour in to take advantage of cheap labour. The structural reforms implemented in recent years and the lifting of the import levy should also help to stimulate the economy. However, the success of the economic recovery will also be heavily dependent upon improvement on the shortage of electricity and other physical infrastructure. Therefore, once the government is able to overcome these constraints, continuous rapid growth is expected to take place in the next decade.

If there is no further major political crisis, the growth momentum of Thailand is expected to be maintained over the next few years though at lower rates than in the previous years. The major stimulus to growth will continue to come from the export of goods and services along with an increase in private and public investment in transportation and communications. However, the shortage of skilled workers coupled with the infrastructural bottlenecks could adversely affect the inflow of foreign investment and could exert upward pressure on inflation.

In Malaysia, economic growth continued to register positive growth. Domestic demand has become a more important force in the economy as incomes rise gradually. New inflows of foreign direct investment may be achieved by measures such as special levy on foreign workers in key economic sectors and the implementation of good and service tax.

The prospect for Singapore is economy remains bright with an average growth of $4.5 \%$ and the manufacturing and service sectors, namely the financial business will remain as major contributors to the rapid growth. In the case of Indonesia, the country is potential growth prospect for future years also remain bright. The worries of the 2015 national elections are over and the government is now seriously concentrating on improving the management of the economy. Contribution from the non-oil sector should remain the major source of growth.

Several factors have contributed to the growth of international business: market expansion, resource acquisition, competitive forces, technological changes, and changes in government trade and investment policies. Market expansion is the most significant catalyst for international business growth. As the productive capacities of firms' factories outgrow the size of their home markets, firms often internationalize their operations to seek new marketing opportunities. In many smaller market economies, such as Singapore, Switzerland and Netherlands, firms quickly recognize that they had to look beyond national boundaries if they were to continue to grow. The home country market is too small. Nestle started shipping milk to 16 different countries from as early as 1875 . 
Competitive forces also spur growth in international business activity. Because of the economies of scale and the financial strength that comes with larger organizational size, smaller firms often have difficulty competing with larger ones. Thus, when a firm's competitors begin to grow by expanding into new foreign markets, the other firms may have little choice but to follow suit. For example in the late 1990s, Heinz, a US food processing firm, decided to increase its international presence because the company felt the need to keep up with its primary competitors such Nestle, Kellogg and Philip Morris by setting up operations in several foreign markets.

Technological changes- particularly in communications, transportation, and information processing- are other important drivers of growth in international business activities. The increasing usage of computers to rapidly handle and process vast quantities of information allows firms to manage offices and factories located in every corner of the globe. Changes in communications technology, such as the manager in a Tokyo office will be able to receive reports from colleagues in Amsterdam, Abidjan, and Auckland in minutes rather than days. These advanced technological equipment make managing a business far easier today than in the past and hence have facilitated expansion into international, markets.

Finally, changes in government trade and investment policies have expanded growth opportunities for international businesses. Economic liberalization measures in many countries in the region saw the structural changes in their economies. In the past 40 years, countries have negotiated reductions in import tariffs and eliminated barriers to FDI within their borders. Many of the reductions were negotiated through World Trade Organization (WTO) agreements and more recently the Trans Pan Pacific Agreement (TPPA) and many other multilateral trade negotiations. To date many of the international trade discussions had been turned into agreements which consequently saw the expansion of international businesses which have become more important to the world's economy.

\section{International Market Entry and Development Mode}

In the last 40 years, starting from the seminal thesis of Stephen Hymer (1976), there have been great advances in understanding the economics of the multinational enterprises. However, the general theory on the formation of multinational corporations remains unsettled. The theories on the development of multinational corporations cover three broad areas: the ownership advantage paradigm, the location advantage model and the internalization of imperfect market paradigm. Among the remarkable contributiors to the field were Vernon (1966), Kindleberger (1969), Caves (1971 and 1974), Dunning (1980), and Buckley and Casson (1976). The general preposition originating from the work of these authors (Hymer, 1976, \& Kindleberger, 1969) was that companies must possess some form of quasimonopolistic advantage in order to compete in an overseas market against domestic firms possessing local knowledge and the advantages of local nationality. On the other hand, Caves (1971) and Dunning (1980) drew attention to the nature of what is now called the 
ownership-specific or firm-specific advantages of foreign enterprises, such as technology and marketing skills, organization and production management, financial variables, size and oligopolistic behavior as the tools that enable firms to operate in the international markets. In the case of multinational firms originating from developing countries, studies on technology exports by Diaz Alejandro, Lecrew and Wells were of significant importance (Lall, 1976). These studies were conducted to investigate the nature of the third world multinationals (Lall, 1976). These studies though did not explicitly focus on the process of the domestic technological development which underlies technology export or which links up to the general idea of international technology flows, were able to distinguish the nature of technology transfers from developing countries. In essence, these studies were able to address the inappropriateness of the developing countries to continuously become passive buyers of inappropriate technology from the west, hence, ensuring the need to have South-South technological co-operation in light of the growing multilateral trade among developing countries.

Westphall (1979) gave insight of the South Korean experiences which stressed on the new mechanism and perspective in promoting international business. These insights demonstrated how learning processes which occur in highly dynamic outward-looking economy will enabled transformation of economic policies thereby giving rise to different revealed comparative advantage that a country can enjoy and allowing the country to increase the extensive use of the export components.

In choosing a mode of entry, Dunning's eclectic theory (1980) suggests that the factors that affect the choice among the entry modes is the extent of a firm's possessing ownershipspecific advantages, location advantages or internalization advantages. These advantages must be considered within the whole context of the firm's needing to have full control of the operation, the availability of factor resources and the overall firm's global strategy. Ownership advantage refers to resources owned by a firm that grant it a competitive advantage over its industry rival (Mohamad \& Mohamad Hanapi 2012). These firm-specific ownership advantages may be tangible or intangible. For example, the ownership by Toronto-based Inco Ltd., of rich nickel-bearing ores has allowed the firm to dominate the production of both primary nickel and nickel-based metal alloys. Assuming that local firms know about their home turf than foreigners do, a foreign firm contemplating entry into a new market should possess some ownership advantage in order to overcome the information advantage of local firms. The nature of the firm's ownership advantage also affects the selection of the entry mode. Embedded technology, for example, can best be transferred through an equity mode, while a simple technology is perhaps more suitable compared to a licensing mode.

Location advantages are another factor that affects the desirability of host country production relative to home country production. Firms routinely compare economic and non-economic characteristics of the home market with those of the foreign market in determining where to locate their production facilities. If home country production is found to be more desirable than host country production, the firm will choose to enter the host country market via exporting. For example, Siam Cement, one of the world's lowest-cost producers, has relied 
on exports from its modern Thailand factories to serve the Cambodian, Vietnam and Laotian markets rather than setting up production facilities in those countries (WTO, 2015).

The desirability of home country versus host country production is affected by many factors. Relative wage rates and land acquisition costs in the countries are important considerations, but firms may also consider surplus or unused capacity in existing factories, usage of R\&D facilities, logistical requirements, the needs of consumers, and the additional administrative costs of managing a foreign facility. Government policies can also have a major influence on production location. For example, high tariff walls, like those imposed by Argentina and Brazil in the 1970s and early 1980s, discourage exporting and encourage local production, while high corporate taxes may inhibit local production. Location advantages may also be culture-bond. For example, locating a factory in China is much easier for an overseas Chinese manufacturer than for a Spanish firm because of the former better understands Chinese culture and social norms. Internalization advantages are those factors that affect the desirability of a firm producing goods or service itself rather than contracting a local host country firm to produce the product. The amount of transaction costs (cost of negotiating, monitoring, and enforcing an agreement) is critical to this decision. If contracts are difficult to negotiate, monitor and enforce, the firm may rely on FDI and joint ventures as entry modes. If transaction costs are low and the firm believes local firms can more efficiently produce the goods or service without jeopardizing its interest, the firm may use franchising and licensing as entry modes. In deciding the optimum method of international operation, the firm must consider both the nature of the ownership advantage it possesses and its ability to ensure productive and harmonious working relations with any local firm with which it does business.

The factors that may have influence the choice should begin with a cursory analysis of the general variables of the host country, including total and per capita GNP, mortality rates, and population figures. Other factors that might influence MNC to go international include marketing factors, for example market size, growth, desire to maintain share of the market, need to maintain close customer contract, dissatisfaction with existing market arrangements, export base, and the desire to follow customers and competition. Barriers to trade, for example government-erected barriers to trade, and preference of local customers for local products may also contribute to the choice of international operations. Others may include cost factors, for example the desire to be near the source of supply, availability of labor, raw materials and technology, lower labor and transport costs. Other factors associated with investment climate one the general attitude toward foreign investment, political stability, limitation of ownership, and familiarity with the host country.

\section{The Profile of Selected Companies and Industries}

As noted in the previous section, the major criterion for a firm to be established as a multinational corporation is the presence of the ownership-specific advantages within the 
firm. It has been suggested that the kind of factors which have been found to link with the ownership-specific advantages are skills, managerial complexity, capital intensity, technical intensity and innovative capability (Mohamad, 2012). It is further observed that these factors which are seen to cause the formation of the multinational corporations are commonly found to be the outcome of the firms' structure, conduct and performance within the industry. There are a variety of methods of classifying international business arrangements. Among the common practices is the distinction between market-servicing methods in terms of risk and control, progressing from export modes through the range of contractual modes such as licensing, to direct investment production modes. This section reports the profile of the firms and industries and the mode of entry into international operations in ASEAN.

From our qualitative surveys and analyses of the macro-economic conditions of ASEAN countries we found that there are similarities in the characteristics of the method of internationalization among ASEAN firms. These characteristics were found to be the existence of high firms and industrial concentration in terms of one aspect of internationalization mode as compared to the other. Internationalization is prevalent in that exporting is more preferable as compared to licensing or franchising though there are resembles of jointventure activities. Exporting is generally recognized as being the least-risk method of internationalization and, as such, normally represents the beginning of the international operation of a firm. It was estimated that in 2015 a total value of USD 2512 billion was in the form of merchandise trade among ASEAN member countries (Table 4). Of this figure, USD 1295 billion was in the form of export and the rest was import. The explanation for the reason why export was more preferable to the ASEAN firms may be viewed from several economic perspectives. Unlike multinational corporations from developed countries where their strengths were in their resources and usage of capital-intensive technology, the firms from developing countries were smaller, used labor-intensive technology and produced unbranded low R \& D, low quality products that competed on the basis of price in developing countries. However, these embedded characteristics of the developing countries firms may not be that strong to offset the possibilities of additional costs of operating on shores but significantly capable of competing through offshore operations. Hence, the choice of internationalization of the firms in the developing countries now rest in the form of exports. The other two modes of internationalization such as licensing and franchising seem to be obscure and of no significance to the ASEAN firms. There is an obvious explanation for the absence of such methodologies. The industry which is characterized with high licensing activities is normally associated with the type of industry that produces consumer products which undergo tremendous amount of research and development activities. One of the common types is the pharmaceutical industry. In developed countries, pharmaceutical firms routinely use licensing as their entry mode. One of the specific features of this industry is that the product is patented in view of the unique medical properties and the requirement for good distribution of local networks. Obtaining either is an expensive venture. Researching, developing, and testing a new wonder drug can cost several hundred million dollars, while distribution networks must be large to be effective. Many such firms prefer to forgo the 
expensive and time-consuming process of setting up overseas production facilities and foreign distribution networks. Instead they grant existing local firms the right to manufacture and distribute the patented drug in return for royalty payments.

Perhaps the other mode of internationalization of ASEAN firms which is gaining momentum and may become the significant channel of international operation in the future is foreign direct investment. It is noted that foreign direct investment by member countries of ASEAN is growing rapidly, initially at lower rates but progressing rapidly in current years. Another interesting feature of foreign direct investment is the growing concern among member countries to invest within the ASEAN region besides the traditional countries of the developed nations. One important strand comes from this operation. At first glance, developing countries' multinational corporations do not possess proprietary skills or knowledge in management, technology or marketing skill comparable to their counterparts from the developed countries. The products of the developing countries' multinational corporations do not compete directly against those of other multinational corporations but are specifically directed to home countries and other countries within the economic realm of the parent companies. This is so because developing countries' firms do not have access to the latest technology, the large amount of capital or expertise necessary for large-scale, capital-intensive technology and hence must be able to introduce appropriate products suitable to such markets. Therefore the suitability of developing countries' foreign direct investment rests on the ability of the firm to produce goods or joint-venture projects at lower cost, or on the ability to operate on a smaller scale with simpler applications and usage of flexible technologies.

As for regional and individual member country analyses, some important dimensions can be observed in Table 4 and Table 5. Most ASEAN exports are directed outside the region. The US, Japan and the European Union (EU) have been the traditional markets. More recently, the destination of exports has become more broad-based with the inclusion of other developing countries. These countries will remain important new markets. This is evident from the fact that exports to China have grown double the total exports from 1990 to 2015 and so do the exports to Singapore, Taiwan and the Middle East countries.

The other change in ASEAN's trade pattern is the emergence of the ASEAN market itself. For many years, exports to the rest of the world grew at a rate much faster than that of intra-ASEAN exports, which reflected a low level of economic integration among ASEAN members despite their geographic proximity. From 2003 to 2013 (Table 4) intra-ASEAN trade grew at a steady pace with an average growth of $7.6 \%$ with the rest of the world, maintaining a share of slightly under $20 \%$ of the total trade. Since 2000, the growth rate of intra-ASEAN exports exceeded that of other exports by a small margin. In 2013, ASEAN exports were recorded at USD 1295 billion while imports were USD 1235 billion.

The composition of ASEAN exports has also undergone a remarkable change over the past 20 years. There has been a big shift from agricultural commodities to manufactured 
goods. As shown in Table 4, particularly the manufacturing sector which, elaborately transformed manufactures, now dominate ASEAN's merchandise trade. Structural change has transformed a number of ASEAN economies from being exporters of agricultural commodities and unprocessed goods into exporters of light manufactures. Although intraASEAN trade has increased in recent years, this trend should not be overstated. The ASEAN economy level of integration remains well below the potential. Some $75 \%$ of intra-ASEAN trade originates from Singapore, the region's entreport and most open economy, where non ASEAN goods, especially crude oil and petroleum, are re-exported to countries inside the region. If crude oil and petroleum products are omitted, intra-ASEAN trade is only $5 \%$ of the total ASEAN exports. It is also noted that among the top 50 corporations in ASEAN, a high \%age of them have their core business in oil-related activities with an accumulative export of USD 239 billion while the import value was USD 311 billion for 2014.

The WTO reported that Singapore's inflationary pressures were falling while wage rises were moderating its rate of GDP growth for 2014 at $7.0 \%$. Export growth was about 20 $\%$ though it has been said that there was a decline in manufacturing strength as foreign investors shun Singapore for cheaper locations especially in other ASEAN countries and China. From Table 4 and Table 5, it is noted that Singapore is total trade has grown from USD 272 billion in 2003 to USD 856 billion in 2013. Singapore is top trading partners were traditionally developed countries at USD 410 billion, ASEAN at USD 128 billion and others at USD 282 billion in 2014. Singapore is intra-industry trade among the top 13 products consisted mainly of electronic goods with the exception of refined petroleum products, polymerization and natural rubber latex. The top 13 product groups, which represented $50.48 \%$ of Singapore's intra-industry trade, show that Singapore's intra-industry trade is widely dispersed among the product groups.

Table 4 and Table 5 show Malaysia is trade performances for the years 2003 and 2013. Malaysia's total exports and imports registered USD 99.4 billion and USD 81.9 billion respectively in 2003 and grew to USD 234 billion in its export and imports of USD 209 billion in 2013. Malaysia's leading export item were electronic and manufacturing products followed by oil and gas and palm oil products while its leading imports were machinery and transport equipment, manufactured goods and chemicals. Malaysia's major ASEAN trading partners are Singapore with export figure of USD12.43 billion followed by Thailand with USD2.27 billion, Indonesia with USD730 million and the Philippines with USD624 million while its import from Singapore was USD8.6 billion, Thailand USD1.51 billion, Indonesia USD961 million and the Philippines at USD328 million. Malaysia's export promotion policies which placed greater emphasis on free trade zones and licensed manufacturing warehouses, have resulted in a high concentration of "sub-contracting" types of goods in its intra-industry trade. Malaysia is still heavily dependent on foreign investment in order to spearhead the industrialization process. Despite the emergence of cheaper production bases of new emerging market economies such as China and Vietnam, foreign proposed investments in Malaysia registered a total value of USD 17.056 billion in 2013. About a quarter of foreign investments were in the electronic and electrical goods sector, where 
companies from the US, Japan and Taiwan predominate. The heavy foreign investment in electronics pushed up growth in the manufacturing sector. Malaysian companies have also started to invest outside Malaysia particularly in other ASEAN countries and China in the construction, infrastructure, and real estates and property development sectors. The figures for this category of investment stood at USD 6.604 billion in 1996.

Thailand recorded a steady growth in her total trade. The value of Thailand is total trade was USD 248.6 billion in 2006 and increased to USD 478.2 in 2013 ( Table 6). The volume of trade between Thailand and other ASEAN countries increased from USD 16.54 billion in 2003 to 102 billion in 2014 with export outnumbering import throughout the years. Thailand is major trading partner was Singapore apart from other ASEAN countries while China is now becoming the main trading nation of ASEAN. The items of trade were mainly petroleum, electronic products and electrical machinery and parts. Thailand's intra-industry trade consists of a broader range of products. With the new inclusion of petroleum, intermediate goods such as electronic, transistors and valves absorb a large share of Thailand's intra-industry trade. Also playing an important role in the intra-trade were precious and semi-precious stones and textile yarn. Thailand's economy has been in its down turn lately following the decrease in its currency and it is envisaged that once the crisis is over the economy will be on the smooth track again.

Indonesia's economy has been improving very much due to support from foreign investment in its development whereby investment commitment from abroad doubled from USD 35 billion in 2003 to almost USD 78 billion in 2014. Much of the foreign investment in the past few years has been aimed at export-oriented industry as Indonesia's policy switched from energy reliance to manufacturing-based economy. It is noted that Indonesia's total trade was recorded at USD 161.8 billion in 2006 and increased to USD 369.1 billion in 2013. In-terms of total trade, ASEAN countries are the primary trading partners followed by developed countries and in more recent cases advent of China as the new economic force in the region. The product groups that contributed the most towards Indonesia's intraindustry trade contrasts with both Malaysia and Thailand with the conspicuous presence of petroleum oils and petroleum products. With electronic products playing a minor role, the goods involved in Indonesia's intra-industry trade were mainly processed fuels and lubricants, and processed industrial supplies which are classified as intermediate goods.

The high tariff barriers among individual member countries may not be a good strategy for regional economic growth, and the fact that the countries largely export the same type of commodities and compete with each other will further deter any possible growth and development of trade within the region. Competition, motivated by individual nationbuilding priorities and the consequent low level of specialization may continue to create a region of low industries. If economic integration is to progress, steps have to be taken to reverse this situation. Removal of barriers to imports from ASEAN members will foster intra-ASEAN trade. It is interesting to note that ASEAN is moving towards the ASEAN community in full fledge. The results will be an expansion of regional trade and acceleration of business growth. 
In the case of corporate performance for the region, in 2015, it was estimated that about 20 companies from ASEAN have the highest capital of over USD 20 billion (Nikkei, 2015) Detailed analysis is presented in Table 8.0. The biggest company is Singapore Telecommunications with the capitalization value of USD 47.00 billion. The other largest companies come mostly from multinational firms in oil, gas, and financial services. Singapore companies dominated the figures followed by Thailand, Malaysia and Indonesia as presented in Table 10.0. The highest profit was recorded by PTT of Thailand at 3.074 billion while for non-oil and non- financial services it was Singapore Telecommunication at 2.901 billion. From these 100 ASEAN companies, 19 companies were involved in oil refining, marketing and trading. 7 companies were involved in car assembly and sales, 6 companies were involved in the consumer electronic sector and the rest were involved in various sectors such as air transport, shipping, property and real estates, telecommunication and others. Also, it is interesting to be note that from these 100 ASEAN companies, 25 companies were originally foreign companies that were mainly involved in the oil trading business and electronic components sectors. One particular explanation for this occurrence could probably be explained by their global business strategy of implementing contractual joint-venture foreign direct investment. The original companies will not be losing their interests in the ownership, and control remains with the parent firm while at the same time they extend their global operation and continue to receive benefits of the local resources.

\section{Conclusion}

The analysis of international supply choice has been approached from a different direction, namely that of the stages of development. Generally we have found that the internationalization model suggests an incremental, evolutionary approach to foreign markets with industries and companies gradually deepening their involvement as they gain experience, confidence and control of the markets. As such the firms of the ASEAN region, specifically, Malaysia, Singapore, Thailand, Indonesia and the Philippines at the initial stage will have experimental involvement in foreign trade via exporting and progressing to the establishment of the export marketing department once active involvement between the countries prevailed. The next stage will see the committed involvement stage where the companies have a long-run commitment to international production. In this latter case, the internationalization process may continue with licensing and production facilities in foreign markets. Apart from the evolutionary stages of international operation of the ASEAN firms, another distinct feature that is revealed is the evolution in terms of product offering. The offering to foreign markets began with goods, thereafter services, and finally system and know-how. While a number of factors are associated in the choice of the international supply method, items such as close proximity, awareness of the target markets, uniqueness of providing firms in terms of products and production processes, and policy regimes constitute the fundamental reasons for such exercises. Finally, the existence of multinational companies from ASEAN will foster greater competition and enhance efficient allocation of resources among member countries in the future. 


\section{References}

Buckley, P. J., \& Casson, M.C. (1976). The future of the multinational enterprises. New York: Macmillan and Holmes Meier.

Buckley, P.J. (1982).The role of exporting in the market servicing policies of multinational enterprises : Theoretical and empirical perspectives. In Czinkota, M. R., \& Tesar, G. (Eds.). Export management: An international context. New York: Praeger.

Caves, R. E. (1971). Multinational enterprise and economic analysis. Cambridge: MIT Press.

Caves. R. E. (1974, May). Multinational firms, competition and productivity in host-country markets. Economica, 41.

Chandler, A. D. (1970). The growth of the transnational industrial firm in the United States and the United Kingdom. Economic History Review, 33, Series 2.

Dunning, J. H. (1980). Toward an eclectic theory of international production: Some empirical tests. Journal of International Business Studies, 11(2), 9-22.

Fortune Magazine. (2015). Global 500. New York: Time Inc.

Hymer, S. H. (1970). The efficiency (contradictions) of multinational corporations. American Economic Review, 60, 441-8.

Kindleberger, C. P. (1969). American business abroad: Six lectures on direct investment. New Haven: Yale University Press.

Lall, S. (1976). Financial and profit performance of multinational corporations in developing countries: Some evidence from Indian and Columbian samples. World Development, 4.

Lall, S. (1982). Export of technology by newly-industrializing countries. Oxford: Oxford University Press.

Mohamad, Mohamad Hanapi. (2012). The antecedents of international business models. Professorial Lecture Series. Universiti Utara Malaysia

Nikkei Asian Review. (2014). ASEAN 100. Tokyo: Nikkei Inc.

Teece, D. J. (1977, June). Technology transfer by multinational firms: The resource of international technology. Economic Journal.

UNCTAD. (2005). Statistical tables 2003. New York and Geneva : United Nations.

UNCTAD. (2006). Statistical tables 2004. New York and Geneva: United Nations.

Vernon, R. (1966, May). International investment and international trade in the product cycle. Quarterly Journal of Economics, 190-207.

Wells, L. T. (1968, July). A product life cycle for international trade? Journal of Marketing, $33,1-6$.

Werstphall, L.E., Rhee, Y.W., \& Purcell, G. (1979). Foreign influence on South Korean industrial development. Oxford Bulletin of Economics and Statistics, 41 (4).

World Bank. (2015). World FDI flows. New York.

World Trade Organization. (2015). World trade statistics. New York and Geneva: United Nations. 
Mohamad Hanapi Mohamad

\section{Appendices}

Table 1. World Merchandise Exports by Region

\section{Table L.5}

World merchandise exports by region and selected economy, 1948, 1953, 1963, 1973, 1983, 1993, 2003 and 2014

(Bilion dollars and percentage)

\begin{tabular}{|c|c|c|c|c|c|c|c|c|}
\hline & 1948 & 1953 & 1963 & 1973 & 1983 & 1993 & 2003 & 2014 \\
\hline & \multicolumn{8}{|c|}{ Value } \\
\hline \multirow[t]{2}{*}{ World } & 59 & 84 & 157 & 579 & 1838 & 3688 & 7380 & 18494 \\
\hline & \multicolumn{8}{|c|}{ Share } \\
\hline World & 100.0 & 100.0 & 100.0 & 100.0 & 100.0 & 100.0 & 100.0 & 100.0 \\
\hline North America & 28.1 & 24.8 & 19.9 & 17.3 & 16.8 & 17.9 & 15.8 & 13.5 \\
\hline United States & 21.7 & 18.8 & 14.9 & 12.3 & 11.2 & 12.6 & 9.8 & 8.8 \\
\hline Canada & 5.5 & 5.2 & 4.3 & 4.6 & 4.2 & 3.9 & 3.7 & 2.6 \\
\hline Mexico & 0.9 & 0.7 & 0.6 & 0.4 & 1.4 & 1.4 & 2.2 & 2.1 \\
\hline South and Central America & 11.3 & 9.7 & 6.4 & 4.3 & 4.5 & 3.0 & 3.0 & 3.8 \\
\hline Brazil & 2.0 & 1.8 & 0.9 & 1.1 & 1.2 & 1.0 & 1.0 & 1.2 \\
\hline Venezuela, Bolivarian Rep. of & 1.5 & 1.7 & 1.5 & 0.6 & 0.8 & 0.4 & 0.4 & 0.4 \\
\hline Europe & 35.1 & 39.4 & 47.8 & 50.9 & 43.5 & 45.3 & 45.9 & 36.8 \\
\hline Germany a & 1.4 & 5.3 & 9.3 & 11.7 & 9.2 & 10.3 & 10.2 & 8.2 \\
\hline Netherlands & 2.0 & 3.0 & 3.6 & 4.7 & 3.5 & 3.8 & 4.0 & 3.6 \\
\hline France & 3.4 & 4.8 & 5.2 & 6.3 & 5.2 & 6.0 & 5.3 & 32. \\
\hline Italy & 1.8 & 1.8 & 3.2 & 3.8 & 4.0 & 4.6 & 4.1 & 2.9 \\
\hline Commonwealth of Independent States (CIS) b & - & - & - & - & - & 1.5 & 2.6 & 4.0 \\
\hline Africa & 7.3 & 6.5 & 5.7 & 4.8 & 4.5 & 2.5 & 2.4 & 3.0 \\
\hline South Africa C & 2.0 & 1.6 & 1.5 & 1.0 & 1.0 & 0.7 & 0.5 & 0.5 \\
\hline Middle East & 2.0 & 2.7 & 3.2 & 4.1 & 6.7 & 3.5 & 4.1 & 7.0 \\
\hline Asia & 14.0 & 13.4 & 12.5 & 14.9 & 19.1 & 26.0 & 26.1 & 32.0 \\
\hline China & 0.9 & 1.2 & 1.3 & 1.0 & 1.2 & 2.5 & 5.9 & 12.7 \\
\hline Japan & 0.4 & 1.5 & 3.5 & 6.4 & 8.0 & 9.8 & 6.4 & 3.7 \\
\hline India & 2.2 & 1.3 & 1.0 & 0.5 & 0.5 & 0.6 & 0.8 & 1.7 \\
\hline Australia and New Zealand & 3.7 & 3.2 & 2.4 & 2.1 & 1.4 & 1.4 & 1.2 & 1.5 \\
\hline Six East Asian traders & 3.4 & 3.0 & 2.5 & 3.6 & 5.8 & 9.6 & 9.6 & 9.6 \\
\hline
\end{tabular}

Memorandum item:

\begin{tabular}{|c|c|c|c|c|c|c|c|c|}
\hline EU d & - & - & 24.5 & 37.0 & 31.3 & 37.3 & 42.4 & 33.3 \\
\hline USSR, Former & 2.2 & 3.5 & 4.6 & 3.7 & 5.0 & - & - & . \\
\hline GATT/WTO Members e & 63.4 & 69.6 & 75.0 & 84.1 & 77.0 & 89.0 & 94.3 & 97.3 \\
\hline
\end{tabular}

a Figures refer to the Fed. Rep. of Gemany from 1948 through 1983.

b Figures are significantly affected by incluaing the mutual trade fows of the Batic States and the CS between 1993 and 2003.

c Beginning with 1998, figures refer to South Africa only and no longer to the Southem African Customs Union.

d Figures refer to the EEC(6) in 1963, EC(9) in 1973, EC(10) in 1983, EU(12) in 1993, EU(25) in 2003 and EU(28) in 2014.

e Mermbership as of the year stated

Note: Beween 1973 and 1983 and beween 1993 and 2003 export shares were significanty infuenced by oil price devel opments. 
Table 2. World Merchandise Imports by Region

\section{Table $\mathbf{L 6}$}

World merchandise imports by region and selected economy, 1948, 1953, 1963, 1973, 1983, 1993, 2003 and 2014

(Bilion dollars and perventage)

\begin{tabular}{|c|c|c|c|c|c|c|c|c|}
\hline & 1948 & 1953 & 1963 & 1973 & 1983 & 1993 & 2003 & 2014 \\
\hline & \multicolumn{8}{|c|}{ Value } \\
\hline \multirow[t]{2}{*}{ World } & 62 & 85 & 164 & 594 & 1883 & 3805 & 7696 & 18641 \\
\hline & \multicolumn{8}{|c|}{ Share } \\
\hline World & 100.0 & 100.0 & 100.0 & 100.0 & 100.0 & 100.0 & 100.0 & 100.0 \\
\hline North America & 18.5 & 20.5 & 16.1 & 17.2 & 18.5 & 21.3 & 22.4 & 17.7 \\
\hline United States & 13.0 & 13.9 & 11.4 & 12.3 & 14.3 & 15.9 & 16.9 & 12.9 \\
\hline Canada & 4.4 & 5.5 & 3.9 & 4.2 & 3.4 & 3.7 & 3.2 & 2.5 \\
\hline Mexico & 1.0 & 0.9 & 0.8 & 0.6 & 0.7 & 1.8 & 2.3 & 22 \\
\hline South and Central America & 10.4 & 8.3 & 6.0 & 4.4 & 3.9 & 3.3 & 2.5 & 4.0 \\
\hline Brazil & 1.8 & 1.6 & 0.9 & 1.2 & 0.9 & 0.7 & 0.7 & 1.3 \\
\hline Chile & 0.4 & 0.4 & 0.4 & 0.2 & 0.2 & 0.3 & 0.3 & 0.4 \\
\hline Europe & 45.3 & 43.7 & 52.0 & 53.3 & 44.1 & 44.5 & 45.0 & 36.4 \\
\hline Germany a & 22 & 4.5 & 8.0 & 9.2 & 8.1 & 9.0 & 7.9 & 6.5 \\
\hline United Kingdom & 13.4 & 11.0 & 8.5 & 6.5 & 5.3 & 5.5 & 5.2 & 3.7 \\
\hline France & 5.5 & 4.9 & 5.3 & 6.4 & 5.6 & 5.7 & 5.2 & 3.6 \\
\hline Netherlands & 3.4 & 3.3 & 4.4 & 4.8 & 3.3 & 3.3 & 3.4 & 3.2 \\
\hline Commonwealth of Independent States (CIS) b & - & - & - & - & - & 1.2 & 1.7 & 2.7 \\
\hline Africa & 8.1 & 7.0 & 5.2 & 3.9 & 4.6 & 2.6 & 2.2 & 3.4 \\
\hline South Africa C & 2.5 & 1.5 & 1.1 & 0.9 & 0.8 & 0.5 & 0.5 & 0.7 \\
\hline Middle East & 1.8 & 2.1 & 2.3 & 2.7 & 6.2 & 3.3 & 2.8 & 42 \\
\hline Asia & 13.9 & 15.1 & 14.1 & 14.9 & 18.5 & 23.5 & 23.5 & 31.5 \\
\hline China & 0.6 & 1.6 & 0.9 & 0.9 & 1.1 & 2.7 & 5.4 & 10.5 \\
\hline Japan & 1.1 & 2.8 & 4.1 & 6.5 & 6.7 & 6.4 & 5.0 & 4.4 \\
\hline India & 2.3 & 1.4 & 1.5 & 0.5 & 0.7 & 0.6 & 0.9 & 2.5 \\
\hline Australia and New Zealand & 2.9 & 2.3 & 2.2 & 1.6 & 1.4 & 1.5 & 1.4 & 1.5 \\
\hline Six East Asian traders & 3.5 & 3.7 & 3.2 & 3.9 & 6.1 & 10.2 & 8.6 & 9.4 \\
\hline \multicolumn{9}{|l|}{ Memorandum item: } \\
\hline EU d & - & - & 25.5 & 37.1 & 31.4 & 36.2 & 41.3 & 32.9 \\
\hline USSR, Former & 1.9 & 3.3 & 4.3 & 3.6 & 4.3 & . & - &. \\
\hline GATTWTO Members e & 58.6 & 66.9 & 75.3 & 85.5 & 79.7 & 89.3 & 96.0 & 97.7 \\
\hline
\end{tabular}

a Figures refer to the Fed. Rep. of Germany from 1948 through 1983.

b Figures are significontly affected by incluaing the mutual trade fows of the Batti States and the CS ketween 1993 and 2003.

c Beginning with 1998, figures refere to South Africa oniy and no longer to the Sourhem African Customs Union.

d. Figures refer to the EEC(6) in 1963, EC(9) in 1973, EC(10) in 1983, EU(12) in 1993, EU(25) in 2003 and EU(28) in 2014.

e Nembership as of the year stated.

Note: Beween 1973 and 1983 and between 1993 and 2003 export shares vere sigrifianty infuenced by oil price developments 
Mohamad Hanapi Mohamad

Table 3. Intra and Inter-regional Merchandise Trade

\section{Table 1.4}

Intra- and inter-regional merchandise trade, 2014

(Bilion dollers and percentsge)

\begin{tabular}{|c|c|c|c|c|c|c|c|c|}
\hline \multirow[b]{2}{*}{ Origin } & \multicolumn{8}{|c|}{ Destination } \\
\hline & $\begin{array}{l}\text { North } \\
\text { America }\end{array}$ & $\begin{array}{l}\text { South and } \\
\text { Central } \\
\text { America }\end{array}$ & Europe & CIS & Africa & Middle East & Asia & World \\
\hline \multicolumn{9}{|l|}{ Value } \\
\hline World & 3195 & 744 & 6792 & 512 & 639 & 780 & 5485 & 18494 \\
\hline North America & 1251 & 214 & 379 & 17 & 43 & 79 & 504 & 2493 \\
\hline South and Central America & 173 & 179 & 114 & 9 & 18 & 17 & 170 & 695 \\
\hline Europe & 540 & 119 & 4665 & 218 & 221 & 229 & 738 & 6810 \\
\hline Commonwealth of Independent States (CIS) & 28 & 7 & 385 & 131 & 16 & 22 & 134 & 735 \\
\hline Africa & 39 & 29 & 201 & 2 & 98 & 18 & 152 & 555 \\
\hline Mddle East & 99 & 11 & 148 & 7 & 36 & 113 & 694 & 1288 \\
\hline Asia & 1065 & 185 & 900 & 127 & 207 & 302 & 3093 & 5917 \\
\hline
\end{tabular}

Share of regional trade flows in each region's total merchandise exports

$\begin{array}{lllllllll}\text { World } & 17.3 & 4.0 & 36.7 & 2.8 & 3.5 & 4.2 & 29.7 & 100.0\end{array}$

\begin{tabular}{lllllllll} 
North America & 50.2 & 8.6 & 15.2 & 0.7 & 1.7 & 3.2 & 20.2 & 100.0 \\
\hline
\end{tabular}

\begin{tabular}{lcccccccc}
\hline South and Central America & 24.8 & 25.8 & 16.4 & 1.4 & 2.5 & 2.4 & 24.5 & 100.0 \\
\hline
\end{tabular}

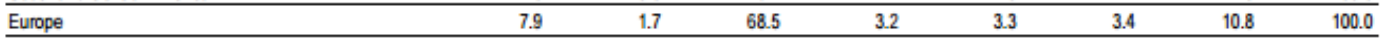

\begin{tabular}{lllllllll}
\hline Commonwealth of Independent States (CIS) & 3.9 & 0.9 & 52.4 & 17.8 & 2.1 & 3.1 & 18.2 & 100.0 \\
\hline
\end{tabular}

\begin{tabular}{lllllllll}
\hline Africa & 7.0 & 5.1 & 36.2 & 0.4 & 17.7 & 3.3 & 27.3 & 100.0 \\
\hline
\end{tabular}

\begin{tabular}{lrrrrrrrr}
\hline Middle East & 7.7 & 0.8 & 11.5 & 0.5 & 2.8 & 8.8 & 53.9 & 100.0 \\
\hline Asia & 18.0 & 3.1 & 152 & 21 & 3.5 & 5.1 & 52.3 & 100.0
\end{tabular}

Share of each region's exports in world merchandise exports to the region

\begin{tabular}{|c|c|c|c|c|c|c|c|c|}
\hline World & 100.0 & 100.0 & 100.0 & 100.0 & 100.0 & 100.0 & 100.0 & 100.0 \\
\hline North America & 39.2 & 28.8 & 5.6 & 3.4 & 6.8 & 10.1 & 9.2 & 13.5 \\
\hline South and Central America & 5.4 & 24.1 & 1.7 & 1.8 & 28 & 2.2 & 3.1 & 3.8 \\
\hline Europe & 16.9 & 16.0 & 68.7 & 42.6 & 34.7 & 29.4 & 13.5 & 36.8 \\
\hline Commonwealth of Independent States (CIS) & 0.9 & 0.9 & 5.7 & 25.6 & 24 & 2.9 & 2.4 & 4.0 \\
\hline Africa & 1.2 & 3.8 & 3.0 & 0.4 & 15.4 & 2.3 & 2.8 & 3.0 \\
\hline Middle East & 3.1 & 1.5 & 2.2 & 1.3 & 5.6 & 14.5 & 12.7 & 7.0 \\
\hline Asia & 33.3 & 24.9 & 13.2 & 24.7 & 32.4 & 38.7 & 56.4 & 32.0 \\
\hline \multicolumn{9}{|c|}{ Share of regional trade flows in world merchandise exports } \\
\hline World & 17.3 & 4.0 & 36.7 & 2.8 & 3.5 & 4.2 & 29.7 & 100.0 \\
\hline North America & 6.8 & 1.2 & 2.0 & 0.1 & 0.2 & 0.4 & 2.7 & 13.5 \\
\hline South and Central America & 0.9 & 1.0 & 0.6 & 0.1 & 0.1 & 0.1 & 0.9 & 3.8 \\
\hline Europe & 2.9 & 0.6 & 25.2 & 1.2 & 1.2 & 1.2 & 4.0 & 36.8 \\
\hline Commonwealth of Independent States (CIS) & 0.2 & 0.0 & 2.1 & 0.7 & 0.1 & 0.1 & 0.7 & 4.0 \\
\hline Africa & 0.2 & 0.2 & 1.1 & 0.0 & 0.5 & 0.1 & 0.8 & 3.0 \\
\hline Middle East & 0.5 & 0.1 & 0.8 & 0.0 & 0.2 & 0.6 & 3.8 & 7.0 \\
\hline Asia & 5.8 & 1.0 & 4.9 & 0.7 & 1.1 & 1.6 & 16.7 & 32.0 \\
\hline
\end{tabular}


Table 4. Merchandise Trade of ASEAN

\section{Table I.19}

\section{Merchandise trade of ASEAN countries by major product group and by origin/destination, 2014}

Billion dollars and percentage

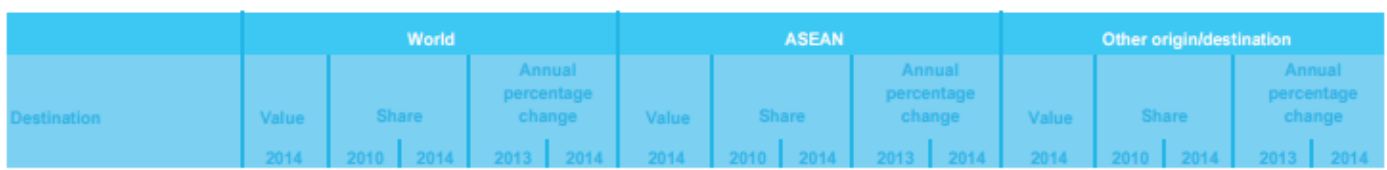

Exports

Indonesia

\begin{tabular}{lrrrrrrrrrrrrrrr} 
Agricultural products & 44 & 22.8 & 24.9 & -5 & 3 & 6 & 18.8 & 16.1 & -21 & 9 & 37 & 23.9 & 27.4 & -2 & 2 \\
\hline Fuels and mining products & 60 & 39.4 & 33.9 & -7 & -15 & 17 & 37.0 & 41.5 & -2 & -3 & 43 & 40.1 & 31.7 & -8 & -19 \\
\hline Manufactures & 70 & 37.0 & 39.6 & 0 & 5 & 16 & 43.4 & 40.1 & 1 & -4 & 54 & 35.3 & 39.4 & 0 & 8 \\
\hline Total exports & 176 & 100.0 & 100.0 & -4 & -3 & 40 & 100.0 & 100.0 & -3 & -2 & 136 & 100.0 & 100.0 & -4 & -4 \\
\hline
\end{tabular}

Malaysia

\begin{tabular}{|c|c|c|c|c|c|c|c|c|c|c|c|c|c|c|c|}
\hline Agricultural products & 30 & 14.5 & 12.9 & -11 & 0 & 7 & 10.2 & 10.5 & -10 & 8 & 23 & 16.0 & 13.8 & -12 & -2 \\
\hline Fuels and mining products & 58 & 17.8 & 25.0 & 13 & 0 & 18 & 20.5 & 28.3 & 16 & 4 & 40 & 16.9 & 23.7 & 11 & -1 \\
\hline Manufactures & 144 & 67.0 & 61.6 & -1 & 4 & 40 & 68.4 & 60.8 & 3 & 1 & 104 & 66.5 & 61.9 & -3 & 6 \\
\hline Total exports & 234 & 100.0 & 100.0 & 0 & 3 & 65 & 100.0 & 100.0 & 5 & 2 & 169 & 100.0 & 100.0 & -1 & 3 \\
\hline
\end{tabular}

Total export

\begin{tabular}{lrrrrrrrrrrrrrrr} 
Agricultural products & 7 & 8.0 & 11.2 & 33 & 3 & 1 & 4.7 & 8.8 & 17 & -11 & 6 & 8.9 & 11.6 & 36 & 5 \\
\hline Fuels and mining products & 6 & 6.2 & 9.5 & 50 & 1 & 1 & 7.8 & 12.4 & 44 & 4 & 5 & 5.8 & 9.0 & 52 & 0 \\
\hline Manufactures & 49 & 85.1 & 78.3 & 3 & 11 & 7 & 87.4 & 78.8 & -15 & 3 & 41 & 84.4 & 78.2 & 7 & 13 \\
\hline Total exports & 62 & 100.0 & 100.0 & 9 & 10 & 9 & 100.0 & 100.0 & -8 & 2 & 53 & 100.0 & 100.0 & 13 & 11 \\
\hline
\end{tabular}

Singapore

Agricultural products

Manufactures

Total exports Thailand

\begin{tabular}{lrrrrrrrrrrrrrrr} 
Agricultural products & 40 & 18.0 & 17.5 & -4 & -1 & 8 & 15.6 & 14.1 & -5 & 3 & 31 & 18.7 & 18.7 & -4 & -3 \\
\hline Fuels and mining products & 15 & 6.2 & 6.6 & -2 & -13 & 9 & 15.6 & 15.8 & -2 & -8 & 6 & 3.5 & 3.3 & -2 & -20 \\
\hline Manufactures & 170 & 72.5 & 74.7 & 3 & 1 & 41 & 68.7 & 68.5 & 6 & 3 & 129 & 73.6 & 76.9 & 2 & 1 \\
\hline Total exports & 228 & 100.0 & 100.0 & 0 & 0 & 59 & 100.0 & 100.0 & 5 & 0 & 168 & 100.0 & 100.0 & -2 & -1 \\
\hline ASEAN & & & & & & & & & & & & & & & \\
Agricultural products & 164 & 12.6 & 12.6 & -3 & 3 & 32 & 9.8 & 9.8 & -8 & 6 & 131 & 13.5 & 13.6 & -1 & 2 \\
\hline Fuels and mining products & 239 & 18.6 & 18.4 & -1 & -6 & 96 & 25.4 & 29.1 & 2 & 0 & 142 & 16.3 & 14.8 & -3 & -10 \\
\hline$\quad$ Manufactures & 850 & 65.2 & 65.7 & 4 & 4 & 197 & 63.0 & 59.5 & 3 & -1 & 654 & 65.9 & 67.8 & 4 & 6 \\
\hline Total exports & 1295 & 100.0 & 100.0 & 2 & 2 & 331 & 100.0 & 100.0 & 2 & 0 & 965 & 100.0 & 100.0 & 1 & 2
\end{tabular}


Imports

Indonesia

\begin{tabular}{lrrrrrrrrrrrrrrr} 
Agricultural products & 22 & 11.5 & 12.5 & 3 & 3 & 3 & 6.2 & 5.6 & -28 & 4 & 19 & 13.7 & 15.2 & 10 & 3 \\
\hline Fuels and mining products & 50 & 23.8 & 27.9 & 5 & -3 & 22 & 40.5 & 43.1 & 7 & -11 & 28 & 17.0 & 21.9 & 4 & 3 \\
\hline Manufactures & 105 & 63.2 & 58.7 & -6 & -6 & 26 & 53.1 & 51.0 & -1 & -2 & 79 & 67.3 & 61.8 & -8 & -8 \\
\hline Total imports & 178 & 100.0 & 100.0 & -3 & -5 & 51 & 100.0 & 100.0 & 0 & -6 & 127 & 100.0 & 100.0 & -4 & -4 \\
\hline Malaysia & & & & & & & &
\end{tabular}

Malaysia

\begin{tabular}{lrrrrrrrrrrrrrrr} 
Agricultural products & 20 & 9.8 & 9.7 & -7 & 1 & 7 & 15.1 & 13.0 & -18 & -3 & 13 & 7.8 & 8.5 & 1 & 3 \\
\hline Fuels and mining products & 47 & 15.1 & 22.5 & 21 & 3 & 17 & 24.0 & 32.3 & 8 & -2 & 30 & 11.8 & 19.1 & 31 & 6 \\
\hline Manufactures & 137 & 73.3 & 65.8 & 2 & 1 & 29 & 59.4 & 53.0 & 1 & -1 & 109 & 78.5 & 70.2 & 2 & 2 \\
\hline Total imports & 209 & 100.0 & 100.0 & 5 & 1 & 54 & 100.0 & 100.0 & 0 & -2 & 155 & 100.0 & 100.0 & 7 & 3 \\
\hline
\end{tabular}

\section{Phillppines}

Agricultural products

Fuels and mining products

\begin{tabular}{lrrrrrrrr} 
Agricultural products & 9 & 11.7 & 12.8 & -1 & 21 & 3 & 16.7 & 15. \\
\hline Fuels and mining products & 15 & 20.7 & 21.8 & -5 & -5 & 3 & 24.9 & 18.8 \\
\hline Manufactures & 44 & 66.8 & 65.0 & 2 & 4 & 11 & 57.9 & 65.2
\end{tabular}

\begin{tabular}{lrrrrrrrr} 
Total imports & 68 & 100.0 & 100.0 & 0 & 4 & 16 & 100.0 & 100.0 \\
\hline
\end{tabular}

Singapore

\begin{tabular}{|c|c|c|c|c|c|c|c|c|c|c|c|c|c|c|c|}
\hline Agricultural products & 15 & 3.5 & 4.0 & 3 & 2 & 5 & 5.8 & 7.2 & -6 & 3 & 9 & 2.8 & 3.2 & 8 & 2 \\
\hline Fuels and mining products & 120 & 27.6 & 32.8 & -5 & -2 & 25 & 22.1 & 33.5 & 1 & -6 & 95 & 29.3 & 32.6 & -7 & -1 \\
\hline Manufactures & 225 & 64.9 & 61.3 & 1 & -2 & 43 & 64.3 & 57.3 & -4 & -2 & 181 & 65.1 & 62.4 & 2 & -1 \\
\hline Total imports & 366 & 100.0 & 100.0 & -2 & -2 & 75 & 100.0 & 100.0 & -2 & -3 & 291 & 100.0 & 100.0 & -2 & -1 \\
\hline \multicolumn{16}{|l|}{ Thailland } \\
\hline Agricultural products & 16 & 6.6 & 7.1 & -2 & -2 & 3 & 6.2 & 6.8 & -11 & 5 & 13 & 6.6 & 7.2 & 0 & -4 \\
\hline Fuels and mining products & 56 & 22.0 & 24.8 & 6 & -7 & 14 & 27.3 & 31.3 & 5 & 0 & 43 & 20.8 & 23.2 & 7 & -10 \\
\hline Manufactures & 148 & 66.8 & 65.1 & -4 & -6 & 27 & 65.6 & 61.4 & 3 & -3 & 122 & 67.0 & 66.0 & -5 & -7 \\
\hline Total imparts & 228 & 100.0 & 100.0 & 1 & -9 & 43 & 100.0 & 100.0 & 3 & -2 & 185 & 100.0 & 100.0 & 0 & -11 \\
\hline \multicolumn{16}{|l|}{ ASEAN } \\
\hline Agricultural products & 103 & 7.7 & 8.3 & 1 & 5 & 27 & 9.6 & 9.7 & -11 & 7 & 76 & 7.1 & 7.9 & 7 & 4 \\
\hline Fuels and mining products & 311 & 22.0 & 25.2 & 2 & -2 & 92 & 27.0 & 33.0 & 3 & -4 & 219 & 20.4 & 22.9 & 2 & -1 \\
\hline Manufactures & 800 & 67.4 & 64.8 & 1 & 0 & 156 & 60.3 & 56.3 & 1 & 0 & 644 & 69.6 & 67.3 & 2 & 0 \\
\hline Total imports & 1235 & 100.0 & 100.0 & 2 & -1 & 278 & 100.0 & 100.0 & 0 & -1 & 957 & 100.0 & 100.0 & 2 & -1 \\
\hline
\end{tabular}


Table 5.

ASEAN Total Trade, Intra-ASEAN and Extra-ASEAN Trade, 2006-2013

(in USȘ Million)

\begin{tabular}{|c|c|c|c|c|c|c|c|c|}
\hline Country & 2006 & 2007 & 2008 & 2009 & 2010 & 2011 & 2012 & 2013 \\
\hline (1) & (2) & (3) & (4) & (5) & (6) & (7) & (8) & (9) \\
\hline \multicolumn{9}{|l|}{ Total Trade } \\
\hline Brunei Darussalam & $9,108.3$ & $9,749.9$ & $12,774.7$ & $9,602.5$ & $10,999.2$ & $14,822.3$ & $16,856.3$ & $15,057.2$ \\
\hline Cambodia & $6,437.4$ & $7,580.6$ & $8,775.5$ & $8,886.7$ & $10,480.3$ & $12,844.1$ & $18,663.7$ & $18,324.2$ \\
\hline Indonesia & $161,864.1$ & $188,574.3$ & $266,217.7$ & $213,339.2$ & $293,442.4$ & $380,932.3$ & $381,721.3$ & $369,180.5$ \\
\hline Lao PDR & 990.2 & $1,093.0$ & $2,630.9$ & $2,962.1$ & $4,509.1$ & $3,955.9$ & $6,158.8$ & $5,884.9$ \\
\hline Malaysia & $285,542.9$ & $323,116.0$ & $338,794.7$ & $280,221.4$ & $363,534.3$ & $415,559.1$ & $423,930.3$ & $434,228.7$ \\
\hline Myanmar & $5,630.2$ & $8,722.5$ & $10,415.4$ & $10,191.3$ & $11,798.3$ & $14,925.1$ & $18,503.3$ & $23,445.4$ \\
\hline Philippines & $99,183.8$ & $105,979.5$ & $105,671.0$ & $83,868.6$ & $109,660.3$ & $111,751.6$ & $117,381.6$ & $119,108.9$ \\
\hline Singapore & $510,516.7$ & $562,451.2$ & $657,985.8$ & $515,616.3$ & $662,658.2$ & $775,167.2$ & $788,116.9$ & $783,265.5$ \\
\hline Thailand & $248,688.3$ & $293,536.8$ & $352,534.2$ & $286,266.8$ & $385,040.8$ & $458,904.4$ & $477,301.9$ & $478,247.3$ \\
\hline Viet Nam & $77,270.5$ & $109,982.5$ & $141,357.0$ & $125,921.9$ & $156,993.1$ & $199,582.1$ & $227,793.3$ & $264,774.0$ \\
\hline TOTAL & $1,405,232.5$ & $1,610,786.3$ & $1,897,157.1$ & $1,536,876.8$ & $2,009,115.9$ & $2,388,444.0$ & $2,476,427.4$ & $2,511,516.5$ \\
\hline
\end{tabular}

Table 6. World Statistics

\section{\begin{tabular}{l|l} 
Table I.1. & $\begin{array}{l}\text { Growth rates of global EDP, GFCF, trade, employment and FDI, 2008-2016 } \\
\text { (Per cent] }\end{array}$
\end{tabular}}

\begin{tabular}{|lrrrrrrrr|r|} 
Variable & 2008 & 2009 & 2010 & 2011 & 2012 & 2013 & 2014 & $2015^{a}$ & $2016^{\mathrm{a}}$ \\
\hline GDP & 1.5 & -2.0 & 4.1 & 2.9 & 2.4 & 2.5 & 2.6 & 2.8 & 3.1 \\
Trade & 3.0 & -10.6 & 12.6 & 6.8 & 2.8 & 3.5 & 3.4 & 3.7 & 4.7 \\
GFCF & 3.0 & -3.5 & 5.7 & 5.5 & 3.9 & 3.2 & 2.9 & 3.0 & 4.7 \\
Employment & 1.2 & 1.1 & 1.2 & 1.4 & 1.4 & 1.4 & 1.3 & 1.3 & 1.2 \\
FDI & -20.4 & -20.4 & 11.9 & 17.7 & -10.3 & 4.6 & -16.3 & 11.4 & 8.4
\end{tabular}

\section{Memorandum}

FDI value (in \$ trillions)

Source: UNCTAD, FDI/MNE database for FDI in 2008-2014; United Nations (2015) for GDP; IMF (2015) for GFCF and trade; IL0 for employment; and UNCTAD estimates for FDI in 2015-2016.

s Projections.

Note: $\quad$ FDl excludes Caribbean offshore financial centres. GFCF $=$ gross fixed capital formation. 
Mohamad Hanapi Mohamad

Table 7. Fortune Global 500

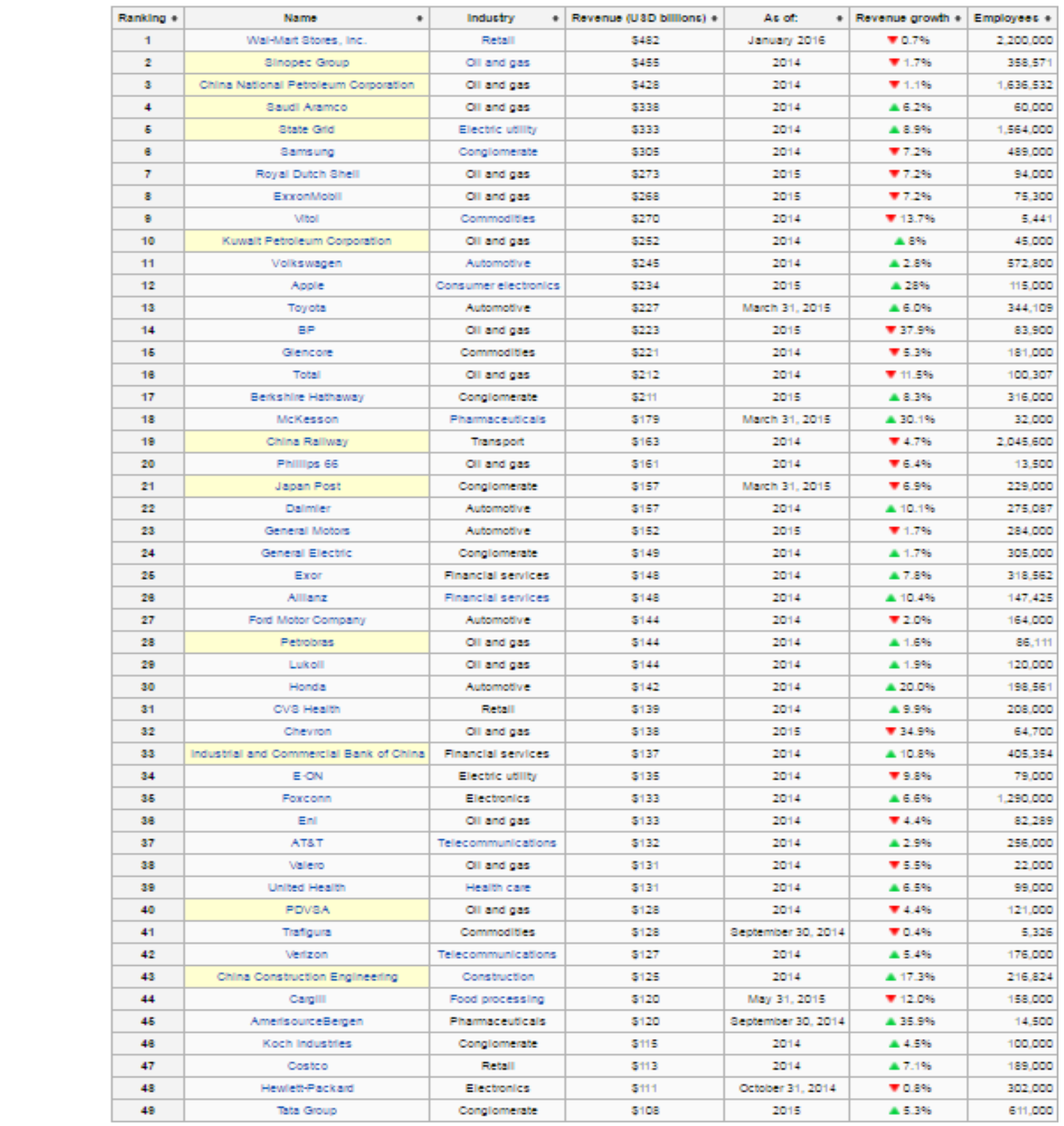


Table 8. ASEAN 100 Largest Corporations

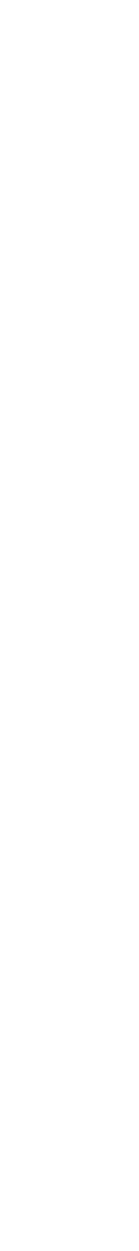

\begin{tabular}{|c|c|c|c|c|c|c|c|c|}
\hline $\begin{array}{l}\text { Top } 50 \text { ASEA } \\
\text { by market ca }\end{array}$ & $\begin{array}{l}\text { N companies } \\
\text { pitalization }\end{array}$ & & $\begin{array}{l}\text { Market } \\
\text { value: } \\
\text { in olions } \\
\text { of dolars }\end{array}$ & Change: & $\begin{array}{l}\text { Net } \\
\text { profit: } \\
\text { of mibonis } \\
\text { of dolars }\end{array}$ & $\begin{array}{l}\text { Rank- } \\
\text { ing } \\
\text { by } \\
\text { pactict }\end{array}$ & $\begin{array}{l}\text { Business } \\
\text { type }\end{array}$ & Company outline \\
\hline rel & $\begin{array}{l}\text { Singapore } \\
\text { Telecommunications }\end{array}$ & $n$ & 47.00 & 22.4 & 2,901 & 3 & $\begin{array}{l}\text { Communica- } \\
\text { Gons }\end{array}$ & $\begin{array}{l}\text { Earns majority of profit abroad through invest- } \\
\text { ment in major regional peers, including SingTel } \\
\text { Optus of Australia }\end{array}$ \\
\hline DBS & DBS Group Holdings & $m$ & 35.73 & 42.8 & 2,934 & 2 & Finance & $\begin{array}{l}\text { Acquired Societe Generale's private banking } \\
\text { business in Singapore, Hong Kong in } 2014\end{array}$ \\
\hline & PTT & $\cong$ & 32.27 & 21.9 & 3,074 & 1 & Oil gas & $\begin{array}{l}\text { Thai state-owned oil energy company: pushing } \\
\text { for resource development overseas }\end{array}$ \\
\hline ank & $\begin{array}{l}\text { Oversea-Chinese } \\
\text { Banking Corp. }\end{array}$ & $=$ & 30.80 & 33.2 & 2,212 & 5 & Finance & $\begin{array}{l}\text { Recently acquired Hong Kong's Wing Hang Bank } \\
\text { to accelerate expansion in mainland China }\end{array}$ \\
\hline UOB & $\begin{array}{l}\text { United } \\
\text { Overseas Bank }\end{array}$ & 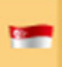 & 28.96 & 29.2 & 2,404 & 4 & Finance & $\begin{array}{l}\text { Strengthening regional foothold by acquiring } \\
\text { smaller banks in Indonesia. Thailand }\end{array}$ \\
\hline ank & Malayan Banking & a & 27.47 & 41.9 & 2,080 & 6 & Finance & $\begin{array}{l}\text { Also known as Maybank: Malaysia's largest } \\
\text { bank by assets; runs largest Islamic bank in } \\
\text { region by assets }\end{array}$ \\
\hline a & BankCentral Asia & $m$ & 26.62 & 86.4 & 1,364 & 15 & Finance & $\begin{array}{l}\text { Major stake owned by ethric Chinese tycoon } \\
\text { Robert Budi Hartono; focuses on corporate banking }\end{array}$ \\
\hline 8 & $\begin{array}{l}\text { Hanjaya Mandala } \\
\text { Sampoerna }\end{array}$ & $=$ & 25.78 & 231.5 & 1,035 & 24 & Tobacco & $\begin{array}{l}\text { Largest tobacco producer in Indonesia; } 98 \% \\
\text { owned by Philip Morris' local subsidiary }\end{array}$ \\
\hline & $\begin{array}{l}\text { Telekomunikasi } \\
\text { Indonesia }\end{array}$ & $=$ & 22.93 & 51.1 & 1,360 & 16 & $\begin{array}{l}\text { Communica- } \\
\text { tons }\end{array}$ & $\begin{array}{l}\text { Majority owned by government, Telkomsel, its } \\
\text { mobile operator, has over } 130 \text { million subscrbers }\end{array}$ \\
\hline & Tenaga Nasional & a & 22.92 & 96.6 & 1,999 & 8 & Utilities & $\begin{array}{l}\text { Generates, distributes power nationwide except } \\
\text { in Sarawak State; mainly uses gas, coal }\end{array}$ \\
\hline & Astra International & $m$ & 22.69 & 18.9 & 1,858 & 9 & $\begin{array}{l}\text { Conglorner- } \\
\text { ate }\end{array}$ & $\begin{array}{l}\text { Irvolved in automaking infrastructure, mining } \\
\text { plantations, banking a core company of Jardine } \\
\text { Matheson group }\end{array}$ \\
\hline 3Ra & $\begin{array}{l}\text { BankRakyat } \\
\text { Indonesia }\end{array}$ & $m$ & 22.60 & 94.4 & 2,043 & 7 & Finance & $\begin{array}{l}\text { Claims to have nearty } 50 \% \text { share of microloan } \\
\text { market (loans of up to about } \$ 8,000 \text { ) }\end{array}$ \\
\hline & Public Bank & a & 21.88 & 60.2 & 1,290 & 19 & Finance & $\begin{array}{l}\text { Leading in property, vehicle mortgages, uninter- } \\
\text { rupted profitability for about } 50 \text { years }\end{array}$ \\
\hline & $\begin{array}{l}\text { Advanced } \\
\text { Info Service }\end{array}$ & $\cong$ & 21.81 & 166.0 & 1,180 & 21 & $\begin{array}{l}\text { Communica- } \\
\text { toons }\end{array}$ & $\begin{array}{l}\text { Mobile service subsidiary of Intouch Holdings: } \\
\text { established by former Prime Minister } \\
\text { Thaksin Shinawatra }\end{array}$ \\
\hline & BankMandiri & 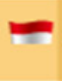 & 19.98 & 64.4 & 1,742 & 11 & Finance & $\begin{array}{l}\text { Created by merger of four banks; includes } \\
\text { brokerage, asset management insurance. } \\
\text { Islamic finance units }\end{array}$ \\
\hline & Unilever Indonesia & $m$ & 19.19 & 74.2 & 512 & 53 & $\begin{array}{l}\text { Consumer } \\
\text { products }\end{array}$ & $\begin{array}{l}\text { Subsidary of Nethertands-based mutinationat } \\
\text { known for kcalied products such as SariWangj } \\
\text { tea Ufebuoy soap }\end{array}$ \\
\hline nomose & $\begin{array}{l}\text { Siam } \\
\text { Commercial Bank }\end{array}$ & 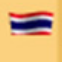 & 18.49 & 73.3 & 1,635 & 12 & Finance & $\begin{array}{l}\text { Thailand's oldest commercial bank largest } \\
\text { sharehoider is Crown Property Bureau }\end{array}$ \\
\hline axiata & Axiata Group & a & 18.38 & 59.5 & 809 & 31 & $\begin{array}{l}\text { Communica- } \\
\text { tons }\end{array}$ & $\begin{array}{l}\text { Has controlling interests in cellular companies } \\
\text { in Malaysia. Indonesia. Sri Lanka. } \\
\text { Bangladesh, Cambodia }\end{array}$ \\
\hline 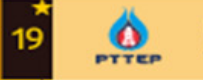 & $\begin{array}{l}\text { PTT Exploration } \\
\text { \& Production }\end{array}$ & $\cong$ & 1785 & 2.5 & 1,827 & 10 & $\begin{array}{l}\text { Oi } \\
\text { exploration }\end{array}$ & $\begin{array}{l}\text { Flagship oil, gas exploration, production arm } \\
\text { of Thai state-owned oil giant PTT }\end{array}$ \\
\hline & Sime Darby & ख & 1784 & 10.6 & 989 & 25 & Agribusiness & $\begin{array}{l}\text { World's largest producer of paim oilt, accounts for } \\
\text { about } 5 \% \text { of global crude paim oil annually }\end{array}$ \\
\hline
\end{tabular}

